\title{
The Relationship between Service Recovery and Patronage Intentions: The Mediating Role of Relationship Quality
}

\author{
Mauro Sciarelli ${ }^{1}$, Abdelhakim A. Nagm ${ }^{2}$, Mona I. Dakrory ${ }^{2}$, Mario Tani ${ }^{1} \&$ Mohamed A. Khashan ${ }^{2}$ \\ ${ }^{1}$ Department of Economics, Management, and Institutions, University of Naples Federico II, Naples, Italy \\ ${ }^{2}$ Department of Business Administration, Faculty of Commerce, Mansoura University, Mansoura, Egypt \\ Correspondence: Mohamed A. Khashan, Department of Business Administration, Mansoura University, \\ Mansoura, Egypt.
}

Received: June 19, 2017

doi:10.5539/ibr.v10n8p215

\author{
Accepted: July 14, 2017 \\ Online Published: July 21, 2017 \\ URL: https://doi.org/10.5539/ibr.v10n8p215
}

\begin{abstract}
This study aims to investigate, using the structural equation modeling with a partial least square (PLS-SEM) approach, the relationship among service recovery strategies, relationship quality, and customer patronage intentions concerning Internet Service Providers (ISPs) in Egypt. Our findings confirmed that some service recovery strategies positively influence on both relationship quality and patronage intentions. As well as, relationship quality has a significant impact on customer patronage intentions. Furthermore, relationship quality has the role of a mediator of the relationship between SR strategies and patronage intention. Moreover, both speeds of recovery and empathy moderate the relationship between some SR strategies and relationship quality. Finally, our study proposed some theoretical and managerial implications.
\end{abstract}

Keywords: service recovery, relationship quality, patronage intentions

\section{Introduction}

Services depend on a high level of interactions between providers and their users. Several authors have considered that this tight relationship increases the chance of a service failure (Hart, Heskett and Sasser, 1989; De- Ruyter and Wetzels, 2000; Chueh, Wang, and Liao, 2014; Komunda and Osarenkhoe, 2012). If service providers' deal with failures in the wrong way they can incur in some harmful consequences as it can drive customers away produce negative WOM, and reduced profits (Tax, Brown and Chandrashekaran, 1998; Bitner, Brown and Meuter, 2000; Tronvoll, 2010). How companies respond to service failure has been found to be a significant factor in both customer attrition (Park and Park, 2016), and customer switching behavior (McCollough, Berry and Yadav, 2000). Mittal, Ross, and Baldasare (1998) hold that a service organization negative performance in responding to service failure have a greater impact on consumer's satisfaction and on their intentions to further purchases compared to a positive performance of the service in the normal situations.

At the same time, service providers can benefit from responding to a service failure in a way customers find satisfying (Najjar, Smith and Kettinger, 2010). Accordingly, Bell and Zemke, (1987) believed that the occurrence of service failure provides a company with a real chance to rebuild consumers' trust and commitment and satisfy them. Therefore, the effective service recovery is one of the main keys to gain an advantage over the competitors, and it has become one of the most important topics in service quality literature (Michel, Bowen and Johnston, 2009).

Wong, Hung, and Chow (2007) confirmed that long-term customer relationships could be considered as one of the most important assets a business organization can have. Despite this, many service companies overlook the sustainable competitive advantage that can be generated through their stable long-term relationships with customers (Morgan and Hunt, 1994; Linares, 2012: p.50), which allows service firms to reduce the negative results related to the unavoidable negative service experiences (Linares, 2012: p.39). In addition, the more positive is the relationship between service provider and its customers, the greater is the customer's likelihood to stay loyal to it and recommend its services to others (Gittell, 2002). Therefore, one of the main objective of marketing relationship management is to strengthen the link with existing customers in order to enhance customer satisfaction (Claycomb and Martin, 2002) and to build customer loyalty through the formation of mutual long-term benefits between service firms and its customers (Kanyan, Andrew, Ali and Beti, 2015). 
Even if customer patronage behavior is surely not a new topic in service marketing literature (Tagashira and Minami, 2016) it is still considered a central strategy for being successful in service industries (Darian, Wiman, and Tucci, 2005; Ganesh, Reynolds and Luckett, 2007; Zolfagharian and Paswan, 2009). Moreover, it represents a major concern for managers because it enables them to identify and target those consumers most likely to purchase (Pan and Zinkhan, 2006, Patney, 2010).

Information and Communications Technology (ICT) is considered one of the core components of a knowledge economy, as well as its role in supporting economic and social development. In the case of Egypt, ICT sector contributes $10.2 \%$ to the Egyptian economic growth, as well as its valuable contribution to the Egyptian GDP (economic indicators of the Egyptian economy's annual and quarterly, the Ministry of Planning, June 2016). It is a noticeable increase in the number of internet Egyptian customers, as the ratio of ADSL subscribers was increased in January-March 2016 compared to January-March 2015 by $22.5 \%$ (Information and Communications Technology Indicators Bulletin, March 2016). These elements have driven the choice of the sector we have focused on in this paper.

Smith (2007) suggests that the effectiveness of various service recovery strategies changes in different settings. So that the service recovery is a contextual phenomenon, needed to be tested in different environments. Moreover, according to Lin (2006), the lack of control on all the service-delivering processes and the need to interact with different customers make services more prone to failures, errors, and complaints than manufacturing products. The interactions open the door to miscommunication, increasing the probability of a service failure.

According to the national telecommunication regulatory authority (NTRA) reports (website: www.tra.gov.eg), the telecommunications sector is more prone to service failure than many others as shown by the relative increase in the number of customers' complaints, as well as the relative delay in dealing with them by some Internet service providers. The reports show that the number of complaints filed by customers is increasing for most companies. In addition, the various providers have not shown a standard period of handling the complaint. This evidence encourages us to explore the perception of ADSL internet customers regarding the provider's service recovery efforts and its relation with relationship quality and patronage intentions in the eastern communities.

This study seeks to explore the role of SR strategies on the quality of the relationship between the service provider and its customers, and how both of them can help to understand customers' patronage intention. In this, we have focused on the internet sector, as these factors have not been tested before in this context. Previous studies have looked into the relationship of service recovery strategies and consumer's re-patronage intentions, and the one between SR strategies and the service recovery satisfaction. In this paper, we advance the existing knowledge complementing these traditional approaches using a broader definition of SR strategies and examining its influence on relationship quality as a whole and on patronage intentions.

\section{Theoretical Background and Hypotheses}

\subsection{Service Recovery $(S R)$}

British Airways used service recovery in 1989 to help focus front-line staff attention on the customer (Li-hua, 2006). According to Zemke and Bell (1990), service recovery is "a thought-out process for returning aggravated customers to a state of satisfaction with the company after a service has failed to exceed the customer's expectations". SR contains all strategies, actions, and tactics a service provider undertakes to respond to a service failure, in order to satisfy customers and retain them (Andreassen, 2000; Miller, Craighead, and Karwan, 2000; Petzer, Steyn and Mostert 2009). It encompasses all the corrective actions to respond to a poor quality service (Gronroos, 1988). According to Boshoff (1999), it is effective only when a company adopts a proactive approach going beyond re-establishing the "normal state".

Service recovery (SR) has been often approached, in service marketing studies, as the results of a combination of strategies the company can adopt in order to deal with service failure. In the following lines, we report the strategies and techniques of service recovery that taken into account:

The first strategy in an SR process is to make an apology (Zemke and Bell, 1990). Apologies let the customer know that the company acknowledges its responsibility for the failure (Ennew and Schoefer, 2003; Liao, 2007). Apologies help in creating an empathic link between company and its customers (Liao, 2007). Some authors (Battaglia, Borchardt, Afonso Sellitto and Medeiros Pereira, 2012; Levesque and McDougall, 2000) suggested that its effectiveness depends on the severity of the failure, and on the willingness to provide some form of compensation. 
The second strategy is problem solving, often seen as the main recovery strategy. It restores the service in its normal state. It also shows the provider's skills in dealing with the failure causes, and in planning and implementing corrective actions (Battaglia et al., 2012). Problem solving should be fast (Parasuraman, Berry and Zeithaml, 1991) and effective (Levesque and McDougall, 2000) as if it fails, it will damage the relationship with the customer.

A third strategy involves explaining the causes of the failure openly. It refers to an explanation of the causes of occurrence the service problem in an obvious and specific way (Conlon and Murray, 1996; Boshoff, 1999). In other words, explain what might have caused the service failure (Liao, 2007). Therefore, it must not be an attempt or a way for the service providers to place the blame on someone else, because it may create negative outcomes (Liao, 2007).

The fourth strategy is about giving some kind of value-added compensation to restore the service value proposition (Boshoff, 1999). It often involves giving back money to the customer and it may be required when the failure could not be fixed (Levesque and McDougall, 2000), other times it comes in the form of free access to future services free and/or discounts (Ennew and Schoefer, 2003).

A fifth strategy to deal with SR is the follow-up. Following-up happens when the company contacts the consumers after recovery efforts to know if he/she has been satisfied with the recovery process itself (Ennew and Schoefer, 2003). Moreover, it refers to the situation in which the service firm provides its consumers with all information needed about his/her complaint and what is being done to resolve it (Boshoff, 1999; Boshoff, Hoogendoorn and van der Kraan, 2005).

Two other factors impact on relationship quality: speed of recovery, and empathy. The speed of recovery can be seen as a way to lessen the customer's difficulties (Battaglia, et al., 2012). Johnston and Clark (2005) hold that finding, and fixing, failures was one of the roots of SR. A delay in response increases the customer resentment and it negati vely affects service quality perception (Boshoff, 1999). An emphatic answer shows that the company cares for the specific interest of each single customer (Zeithaml, Parasuraman, and Berry, 1990, p. 26) and that it tries to reduce his/hers inconvenience (Boshoff, 1999). According to Liao (2007), SR itself asks for an empathizing employee's behavior in dealing with affected customers; employees should understand the customer perspective (Krishna, Dangayach, and Jain, 2011; Battaglia et al., 2012).

\subsection{Relationship Quality $(R Q)$}

Relationship quality is the degree in which the relationship may help consumers in fulfilling some of their needs (Hennig-Thurau and Klee, 1997; p. 752). It also refers to the consumer's overall assessment of the relationship strength and the extent to which it fulfills the consumer's expectations based on their experience with the business firm (Crosby, Evans, Cowles, 1990; Smith, 1998, p. 78). Relationship quality literature confirmed that it is a multi-dimensional construct, which consists of three interrelated constructs namely customer satisfaction, trust, and commitment that may help to reduce consumer's uncertainty feelings concerning its relation with the service provider (Morgan and Hunt, 1994; Dorsch, Swanson, Kelley, 1998; Woo and Ennew, 2004; Vesel and Zabkar, 2010; Doaei, Rezaei and Khajei, 2011; Kim Jung-Eun and Lee, 2012).

Customer satisfaction is usually considered as a central element in the relationship marketing literature. Generally, satisfaction pointed to the customer's fulfillment response, it is a judgment that a product or service characteristics, or the product or service itself, may be used to reach a satisfying level of consumption-related fulfillment (Oliver, 1997, p. 13). In 1981 (p. 27), Oliver defines customer satisfaction as "Summary emotional state resulting when the emotion surrounding disconfirmed expectations is coupled with the consumer's prior feelings about the consumption experience"(Andreassen, 2000). Choi and La (2013), suggest that service recovery satisfaction (SRS), sometimes referred to as the complaint handling (Tax et al. 1998; Orsingher, Valentini and De Angelis, 2010), is the customer's assessment of how a service failure handled by the service provider. It is also described as the degree to which the consumer has promising or satisfactory feelings toward the provider recovery activities (Chang, 2004). So that, SRS is a critical issue because of its role in maintaining and strengthening the relationship between service provider and its customers (Fornell and Wernerfelt, 1987).

Customer Trust is the second pillar in this relationship quality. Anderson and Weitz, (1989) defined it as "one party's belief that its needs will be fulfilled in the future by actions undertaken by the other party" (p. 312). Moorman, Deshpande, and Zaltman (1993) argue that trust is the consumer's belief or attitude toward the service provider integrity, they included in trust both attitudinal (belief, trustworthiness, confidence) and behavioral intention (reliance). Therefore, Moorman et al. (1993) define customer trust as "a willingness to rely on an exchange partner in whom one has confidence"(p. 315). Morgan and Hunt (1994) define it as "confidence in an exchange partner's reliability and integrity "(p. 23). Therefore, both definitions of Moorman et al. (1993) and 
Morgan and Hunt (1994) emphasize the importance of confidence in exchange partner's (Ok, 2004).

Last, but not least there is the Customer commitment. It has a great importance in building relationships with customers as it seen as the key predictor of customer retention (Morgan and Hunt, 1994). Moorman, Zaltman, and Deshpande (1992) defined commitment as "a continuing desire to keep a valued relationship" (p.316). Likewise, Morgan and Hunt (1994) defined it as "an exchange partner believing that an ongoing relationship with another is so important as to warrant maximum efforts at maintaining it". Building on Morgan and Hunt's (1994) definition Lacey, Suh and Morgan (2007) described it as a customer's continuous desire to stay in the relationship with a firm accompanied by his or her willingness to make efforts at maintaining that relationship. It has been defined as an inner desire to maintain a relationship with the service provider over time (Ok, 2004; Jones, Fox, Taylor and Fabrigar 2010).

\subsection{Patronage Intentions (PI)}

According to Rust et al. (1999) patronage intention is the customer's attitude towards the service firm as it refers to the combined effect of his/her various evaluations of the firm service dimensions (Zolfagharian and Paswan, 2009; Patney, 2010). It is an overall measure capturing likelihood and willingness to shop from the service provider, willingness to recommend to others and willingness to revisit (Grewal, Baker, Levy and Voss, 2003). It also refers to loyalty for the shopping mall, the likelihood of returning to the shop, and the likelihood of recommending the mall to others (Rahman, Wong and Yu, 2016). It contains WOM intentions, willingness to pay more, future switching intentions, intention to purchase, and repurchase/repatronage intention (Diddi and Niehm, 2016).

\subsection{Service Recoveryand Patronage Intentions}

Starting from service failure implicitly defined as a problem of service quality (Gronroos, 1988, p. 13). Gronroos (1988) mentioned that service recovery after failure was to be considered as the provider's reaction to its poor service quality and he considered it as part of service quality dimensions. Prior studies have conf irmed a direct influence of service quality on both repurchase intentions and willingness to recommend (Zeithaml, Berry and Parasuraman, 1996). Baker, Parasuraman, Grewal, and Voss. (2002) also stated that customer perceptions of interpersonal service quality influence his/hers patronage intentions towards the company. Ogwo and Igwe (2012) found that service quality has affected positively on customer patronage. Moreover, service quality (i.e. reliability, personal interaction, and problem solving) directly influences customer's retail patronage intentions (Lee, Fairhust and Lee, 2009). In addition, Wirtz and Mattila (2004) confirmed that SR dimensions (compensation, recovery speed, and apology) effects on repatronage/repurchase intentions -as a part of patronage intentions according to Sadachar (2014), and Diddi and Niehm (2016). Therefore, we propose the following set of hypotheses:

H1: (from a to e): Each service recovery strategy (Making an apology; Problem Solving; Providing Explanations; Compensation; Follow-up) has a significant positive effect on patronage intentions.

\subsection{Service Recovery and Relationship Quality}

Based on the literature review, the attributes of satisfaction, trust and commitment are the factors needed to measure the relationship quality construct. Previous studies found that some service recovery dimensions had a direct effect on service recovery satisfaction as a dimension of relationship quality (Tax et al., 1998; Wirtz and Mattila, 2004; Duffy, Miller and Bexley, 2006; Kim, 2007; Komunda and Osarenkhoe, 2012; Yaya, Marimon and Casadesus, 2013; Kandulapati and Bellamkonda, 2014; Stratemeyer, Geringer and Canton, 2014; Mostafa, Lages, and Sääksjärvi, 2014). In addition, SR justice further leads to customers trust (DeWitt, Nhuyen and Marshall, 2008). Therefore, we propose the following hypotheses:

$\mathrm{H} 2$ : (from a to e): Each service recovery strategy (Making an apology; Problem Solving; Providing Explanations; Compensation; Follow-up) has a significant positive effect on relationship quality.

\subsection{Relationship Quality and Patronage Intentions}

Park, Choi, Kim, and Rho (2015) confirmed that customer trust has a direct effect on patronage intentions. In addition, customer satisfaction affects directly patronage intentions (Sadachar, 2014; Sharma, 2015). Furthermore, customer satisfaction affects on behavioral responses, repatronage/ repurchase intentions (Choi and Chu, 2001; Wirtz and Mattila, 2004). Moreover, Wirtz and Mattila (2004) have found that SRS fully mediates the relationship between three SR strategies namely: apologizing, compensation, speed of recovery and repatronage/repurchase intentions. Therefore, we formulate the following hypotheses:

H3: Relationship quality has a positive effect on patronage intentions. 
H4: (from a to e): Relationship quality mediates the positive effect of each service recovery strategy (Making an apology; Problem Solving; Providing Explanations; Compensation; Follow-up) on patronage intentions.

\subsection{Speed of Recovery and Empathy Moderate Service Recovery Strategies Effect on Relationship Quality}

The speed of Recovery is a way to reduce the customer's difficulties related to a given service failure (Battaglia, et al., 2012). A fast response can help in creating a more positive customer's service perception (Boshoff, 1999). At the same time, customers expect the company to acknowledge the difficulties service failures are imposing on them and they expect to be dealt with in an emphatic way. This behavior can be considered as a proxy for how much the company really cares about the customer's satisfaction (Zeithaml et al., 1990, p. 26). According to Liao (2007), these two elements are so important that they could even be considered as specific dimensions of Service Recovery. Other scholars have found that they are needed to really understand the customer perspective and to relate with him (Krishna et al., 2011; Battaglia et al., 2012).Therefore, we propose the following set of hypotheses:

H5: (from a to e): Speed of recovery moderates the positive relationship between each service recovery strategy (Making an apology; Problem Solving; Providing Explanations; Compensation; Follow-up) and relationship quality

H6: (from a to e): Empathy moderates the positive relationship between each service recovery strategy (Making an apology; Problem Solving; Providing Explanations; Compensation; Follow-up) and relationship quality

We illustrate the theoretical model in the figure (1).

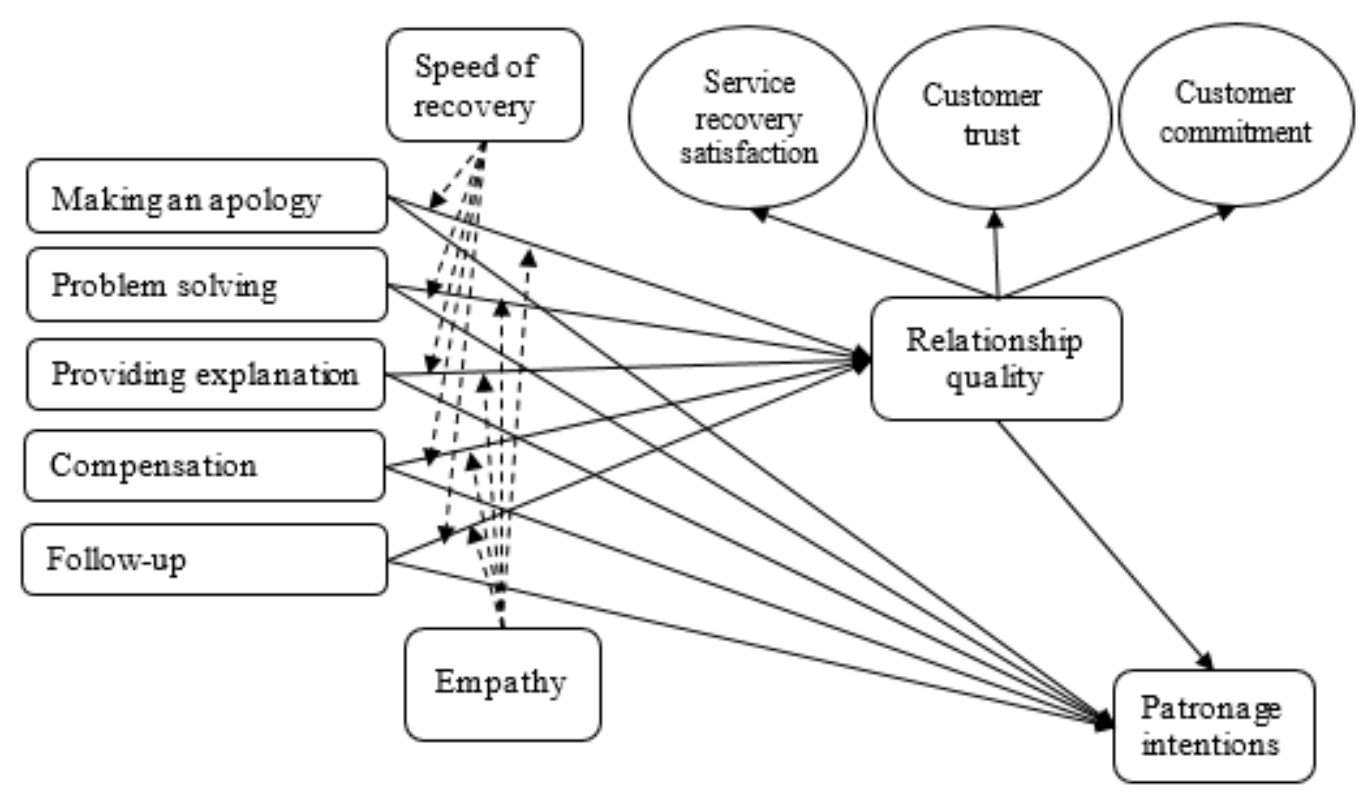

Figure 1. The theoretical model

\section{Method}

\subsection{Measures}

To measure service recovery strategies, we have combined several different measures defined and validated in the literature (Boshoff, 1999; Boshoff et al., 2005, Kau and Loh, 2006; Kim, 2007; Liao, 2007; Del Rio-Lanza, Vázquez-Casielles, and Díaz-Martín; 2009). To measure relationship quality we depend on the measure developed by Kim et al. (2012). In order to measure patronage intentions, we have adopted the scale defined by Grewal et al. (2003) and we have combined it with items of the scale from Zolfagharian and Paswan (2009). In the end, we have used 25 items to measure service recovery, 13 items for relationship quality; and 3 items for patronage intentions rated on a 5 -point Likert scale (from 1 - fully disagree to 5 - fully agree).

\subsection{Sample and Data Collection}

We have decided to survey a sample of the Egyptian internet service user with high-speed ADSL lines in Dakahlia governorate. To sample this population and to distribute the questionnaire, which we have de veloped according to the literature review, we have used a social network service (Facebook) and the service provider's sites; the participants could access the Internet-based questionnaires (online survey) using Google drive as the 
platform. The sampling process lasted 1 month from April 28th to May 27th, 2016. The number of complete questionnaires is 430 .

The questionnaire was revised after a pilot test needed to evaluate the validity and reliability of its items. The initial version was administered to people that had already suffered service failure and to several Internet professionals, to ensure that the target respondents understood the scales used. Then, we gathered data from sample units. Meanwhile, there is no a definite list of Egyptian internet subscribers we have used the convenience sampling in order to collect our data from respondents (San Martín and Herrero, 2012).

The procedures of collecting our data from respondents were sub-divided into two stages. Firstly, two filtering questions were asked to ensure that the respondents were effectively living in the Dakahlia governorate then a second question was used to identify those who had been exposed to a service failure by their current ISP. Another step to assure the questionnaire validity was to include in it two reverse items. All the respondent features showed in the table (1).

\section{Analysis and Results}

We have analyzed our data using a PLS-SEM approach, as it is less sensitive to the multivariate normal distribution dilemma (Wang, Yeh, and Liao, 2013), moreover it is more suitable to analyze small sample sizes, and/or models with a large number of constructs, finally it is considered a good approach to avoid the multicollinearity issue in traditional SEMs (Cassel, Hackl and Westlund, 2000; Yaya et al., 2013). We have processed data using the WarpPLS software using a two steps approach, first we estimated the measurement model and then we have tested our research hypotheses (Fornell and Cha, 1994).

In order to estimate the accuracy of the PLS estimate, we have used the non-parametric techniques of resampling as bootstrapping or jackknifing (Ali, 2016: p.241). Bootstrapping method depends on the "resampling with replacement" method, which refers to that each resample holds a random arrangement of cases of the original dataset, as some cases may be repeated more than once, while some cases may not be involved at all (Sarstedt, Ringle, Smith, Reams, and Hair, 2014; p.130). Otherwise, jackknifing resampling method generates a number of resamples that equals the original sample size, and each resamples has one case deleted (Ali, 2016: p.241).

Based on the relevant advantages of jackknifing, we have chosen to adopt it (with 430 resamples) in the current study to assess the significance of both direct and indirect (mediated) parameter estimates regarding the measurement and structural models.

Table 1. Respondent characteristics

\begin{tabular}{|c|c|c|}
\hline Characteristics & Number & $(\%)$ \\
\hline \multicolumn{3}{|l|}{ Gender } \\
\hline Male & 256 & 59.5 \\
\hline Female & 174 & 40.5 \\
\hline \multicolumn{3}{|l|}{ Age } \\
\hline Less than 20 years old & 38 & 8.8 \\
\hline 20 to less than 35 years old & 351 & 81.6 \\
\hline 35 years old and older & 41 & 9.6 \\
\hline \multicolumn{3}{|l|}{ Service provider } \\
\hline TE-DATA & 304 & 70.7 \\
\hline Vodafone & 58 & 13.5 \\
\hline Etisalat & 39 & 9.1 \\
\hline LinkDSL (Orange) & 29 & 6.7 \\
\hline \multicolumn{3}{|l|}{ Inte rnet bundle (Package) } \\
\hline $1 \mathrm{Mb}$ and less & 266 & 61.8 \\
\hline $2 \mathrm{Mb}$ & 176 & 27 \\
\hline $4 \mathrm{Mb}$ and more & 48 & 11.2 \\
\hline
\end{tabular}

\subsection{Measurement Model}

This study has been built using a reflective measurement model. Both the construct measure's indicator reliability and internal consistency reliability are used to assess the constructs reliability, as well as, both convergent validity and discriminant validity are used to assess the validity of the constructs (Klarner, Sarstedt, Hoeck and Ringle, 2013).

The results support indicator reliability as all items loadings are over 0.50 , so they are considered as statistically significant (Hair, Black, Babin, Anderson, and Tatham. 2006). Hair et al. (2006) proposed that though "generally agreed" lower limit for Cronbach's alpha value is 0.70 , it still be acceptable if it reaches to 0.60 especially in social science. The results also support internal consistency of each construct as CR is greater than 0.7 (Fornell and Larcker, 1981). So, the measures are reliable and the details of this analysis are given in Table 2. 
The constructs' AVEs are over 0.50, so they have convergent validity (Fornell and Larcker 1981; Hair et al. 2006), the details of this analysis are given in Table 2. The square root of the average variance extracted AVE is greater than all the other correlations in all the cases, thus confirming discriminant validity as illustrated in the following Table 3. Thus, the measurement model confirmed appropriate reliability and validity of study constructs.

Table 2. loadings, Reliability, and Convergent Validity

\begin{tabular}{|c|c|c|c|c|c|c|c|}
\hline Dimension & Item Code & Mean & S.D. & loadings & $\mathbf{C R}$ & Cronbach's $\alpha$ & AVE \\
\hline \multicolumn{8}{|l|}{ Service recovery } \\
\hline \multirow{5}{*}{ A.Making an apology } & SR1 & 3.49 & 1.13 & 0.705 & 0.882 & 0.832 & 0.600 \\
\hline & SR2 & 2.69 & 1.15 & 0.793 & & & \\
\hline & SR3 & 2.69 & 1.23 & 0.857 & & & \\
\hline & SR4 & 2.23 & 1.15 & 0.747 & & & \\
\hline & SR5 & 2.81 & 1.12 & 0.765 & & & \\
\hline \multirow{5}{*}{ B.Problem solving } & SR6 & 3.01 & 1.14 & 0.820 & 0.911 & 0.878 & 0.672 \\
\hline & SR7 & 2.92 & 1.10 & 0.816 & & & \\
\hline & SR8 & 2.83 & 1.10 & 0.829 & & & \\
\hline & SR9 & 2.86 & 1.07 & 0.857 & & & \\
\hline & SR10 & 3.04 & 1.13 & 0.773 & & & \\
\hline \multirow{4}{*}{ C.Providing an explanation } & SR11 & 3.55 & 1.05 & 0.711 & 0.879 & 0.815 & 0.646 \\
\hline & SR12 & 3.18 & 1.16 & 0.816 & & & \\
\hline & SR13 & 2.87 & 1.12 & 0.819 & & & \\
\hline & SR14 & 3.05 & 1.12 & 0.861 & & & \\
\hline \multirow{2}{*}{ D.Speed of recovery } & SR15 & 3.16 & 1.12 & 0.852 & 0.841 & 0.623 & 0.726 \\
\hline & SR16 & 2.61 & 1.08 & 0.852 & & & \\
\hline \multirow[t]{4}{*}{ E. Empathy } & SR17 & 3.80 & 0.96 & 0.823 & 0.863 & 0.761 & 0.678 \\
\hline & SR18 & 3.66 & 0.98 & 0.872 & & & \\
\hline & SR19 & 3.13 & 1.09 & 0.772 & & & \\
\hline & SR20 & 1.89 & 1.00 & 0.910 & 0.947 & 0.915 & 0.855 \\
\hline \multirow[t]{3}{*}{ F. Compensation } & SR21 & 1.96 & 1.07 & 0.934 & & & \\
\hline & SR22 & 1.96 & 1.04 & 0.930 & & & \\
\hline & SR23 & 2.62 & 1.17 & 0.849 & 0.902 & 0.836 & 0.754 \\
\hline \multirow[t]{2}{*}{ G.Follow-up } & SR24 & 2.57 & 1.15 & 0.892 & & & \\
\hline & SR25 & 2.45 & 1.22 & 0.863 & & & \\
\hline Relationship Quality & & & & & 0.944 & 0.911 & 0.849 \\
\hline \multirow{6}{*}{ A.Service recovery satisfaction } & SRS1 & 2.48 & 1.07 & 0.695 & & & \\
\hline & SRS2 & 2.40 & 1.03 & 0.670 & & & \\
\hline & SRS3 & 2.64 & 1.07 & 0.808 & & & \\
\hline & SRS4 & 2.77 & 1.04 & 0.811 & & & \\
\hline & SRS5 & 2.74 & 1.17 & 0.845 & & & \\
\hline & CT1 & 2.78 & 1.05 & 0.838 & & & \\
\hline \multirow{2}{*}{ B. Customer Trust } & CT2 & 2.92 & 1.10 & 0.872 & & & \\
\hline & CT3 & 2.92 & 1.09 & 0.817 & & & \\
\hline \multirow{5}{*}{ C.Customer Commitment } & CT4 & 2.63 & 1.09 & 0.842 & & & \\
\hline & $\mathrm{CC} 1$ & 2.51 & 1.10 & 0.758 & & & \\
\hline & $\mathrm{CC} 2$ & 2.74 & 1.07 & 0.829 & & & \\
\hline & CC 3 & 2.55 & 1.04 & 0.822 & & & \\
\hline & $\mathrm{CC} 4$ & 2.70 & 1.04 & 0.836 & & & \\
\hline \multirow[t]{4}{*}{ Patronage intentions } & & & & & 0.903 & 0.839 & 0.756 \\
\hline & R I 1 & 2.85 & 1.16 & 0.858 & & & \\
\hline & R I 2 & 2.87 & 1.21 & 0.871 & & & \\
\hline & R I 3 & 3.20 & 1.12 & 0.880 & & & \\
\hline
\end{tabular}

\subsection{Structural Model (Testing Hypothesis)}

A structural model aims to test the proposed hypotheses, as it described as causal relations between latent variables. According to Klarner et al. (2013), the researchers engaged in a step-by-step analysis of the structural model to test Hypotheses from 1 to 6 comprehensibly. To begin with, in step 1 of the analysis, we only focused on the direct relationships between variables (Hypotheses 1,2 and 3), after that we assessed the full PLS path model and, more specifically the mediator variable (Hypotheses 4). Subsequently, we tested the moderator variables (Hypotheses 5 and 6).

According to PLS-SEM, the evaluation of the model's fit depends on its ability to predict the dependent 
constructs. The assessment criteria are coefficient of determination (R2), predictive relevance (Q2) and the path coefficients (Sarstedt et al., 2014). The overall fit of the model will be evaluated using the following measures: Average Path Coefficient (APC); Average R-squared (ARS), Average Variance Inflation Factor (AVIF), and the Global Goodness of Fit Index (GoF). Kock (2012) recommended that APC and ARS were significant $(\mathrm{P}<0.05)$ whilst the AVIF value ought to be below five. In addition, Tenenhaus GoF of $\geq 0.1, \geq 0.25$, and $\geq 0.36$ indicate that the model has a small, medium, and large goodness of fit index (Tenenhaus et al., 2004).

Table 3. Correlations among latent variables with square roots of AVEs

\begin{tabular}{|c|c|c|c|c|c|c|c|c|c|}
\hline & MA & PS & PE & COM & FOL & SPE & EMP & RQ & PI \\
\hline MA & $(0.775)$ & & & & & & & & \\
\hline PS & 0.617 & $(0.820)$ & & & & & & & \\
\hline PE & 0.552 & 0.748 & $(0.804)$ & & & & & & \\
\hline SPE & 0.478 & 0.415 & 0.383 & $(0.925)$ & & & & & \\
\hline EMP & 0.473 & 0.479 & 0.471 & 0.604 & $(0.868)$ & & & & \\
\hline COM & 0.485 & 0.676 & 0.668 & 0.403 & 0.448 & $(0.852)$ & & & \\
\hline FOL & 0.486 & 0.614 & 0.644 & 0.315 & 0.421 & 0.575 & $(0.823)$ & & \\
\hline RQ & 0.548 & 0.737 & 0.693 & 0.549 & 0.584 & 0.644 & 0.556 & $(0.921)$ & \\
\hline PI & 0.374 & 0.545 & 0.503 & 0.365 & 0.411 & 0.423 & 0.459 & 0.755 & $(0.869)$ \\
\hline
\end{tabular}

Making an apology $=$ MA, Problem solving $=$ PS, Providing explanation $=$ PE, Speed of recovery $=$ SPE, Empathy $=$ EMP, Compensation $=$ COM, Follow-up $=$ FOL, Relationship quality $=$ RQ, Patronage intentions $=$ PI.

Our data has given the model a significant APC $(0.116, \mathrm{P}=0.004)$, a significant ARS $(0.653, \mathrm{P}<0.001)$, an appropriate value of AVIF (2.483). In addition, GoF was 0.640 , which is usually sees as a "good" model fit. The overall results depicted in Table $(4,5$, and 6$)$.

In step 1, we found that the set of hypotheses H1 was partially supported. In particular we have found that the stronger effect on PI comes from the problem solving strategy $(\beta=0.336$, $p$-value $<0.001)$, followed by providing an explanation $(\beta=0.164$, p-value $<0.001)$, and then follow-up $(\beta=0.118$, p-value $=0.007)$. Surprisingly the strategy of giving a compensation $(\beta=0.104$, p-value $=0.015)$ had a lower, but significant, effect on patronage intentions. We have found no evidence on an effect of making an apology on PI (p-value: $0.422)$.

We have similar results for the $\mathrm{H} 2$ set of hypotheses. We found a significant positive effect from problem solving strategy $(\beta=0.393$, $p$-value $<0.001)$, providing an explanation $(\beta=0.241$, $\mathrm{p}$-value $<0.001)$, and then there is the strategy of giving a compensation to the customer $(\beta=0.193, \mathrm{p}$-value $<0.001)$. Follow-up have a significant effect on RQ $(\beta=0.140$, p-value $=0.002)$. Even in testing this set of hypotheses, we have found no significant effect of the making an apology strategy (p-value $=0.263)$.

Finally, H3 was fully supported as relationship quality has a strong, significant, positive effect on PI ( $\beta=0.833$, p-value $<0.001$ )

The results showed that R2 of PI is 0.359 , meaning that service recovery strategies as a whole can explain about $36 \%$ of the variation in internet customer's PI as a dependent variable. The R2 of SR strategies, as a whole, on RQ is 0.627 . The Q2 value of PI $(0.355)$ and RQ $(0.663)$, which indicates the large predictive relevance of the PLS path model.

Table 4. The Path Coefficients, P-value

\begin{tabular}{lcccl}
\hline H & $\begin{array}{c}\text { Exogenous } \\
\text { variables }\end{array}$ & $\begin{array}{c}\text { Endogenous } \\
\text { Variables }\end{array}$ & $\begin{array}{c}\text { Path } \\
\text { coefficients }\end{array}$ & P-value \\
\hline H1a & Apology & PI & 0.010 & 0.422 \\
H1b & P. Solving & PI & 0.336 & $<0.001^{* *}$ \\
H1c & Explanation & PI & 0.164 & $<0.001^{* *}$ \\
H1d & Compensation & PI & 0.104 & $0.015^{*}$ \\
H1e & Follow-Up & PI & 0.118 & $0.007^{* *}$ \\
H2a & Apology & RQ & -0.030 & 0.263 \\
H2b & P. Solving & RQ & 0.393 & $<0.001^{* *}$ \\
H2c & Explanation & RQ & 0.241 & $<0.001^{* *}$ \\
H2d & Compensation & RQ & 0.193 & $<0.001^{* *}$ \\
H2e & Follow-Up & RQ & 0.140 & $0.002^{* *}$ \\
H3 & RQ & PI & 0.833 & $<0.001^{* *}$ \\
\hline Relation
\end{tabular}

Relationship quality $=$ RQ, Patronage intentions $=$ PI. $-*$ Significant at $0.05, * *$ significant at 0.01

Then, in step 2 , we have found that relationship quality fully mediated the positive relationship between problem solving $(\beta=0.327$, $p$-value $<0.001)$, providing explanation $(\beta=0.201$, $p$-value $<0.001)$, compensation $(\beta=0.161$, 
p-value $<0.001)$, follow-up ( $\beta=0.117$, p-value $<0.001)$ and patronage intentions. The results refer to R2 of PI is 0.685 , meaning that service recovery strategies explain about $69 \%$ of the variation in internet customer's PI as a dependent variable. The Q2 value of PI is (0.593), indicating that the model has a great predictive relevance. So, the hypotheses $\mathrm{H} 4$ can be considered partially supported.

Table 5. Indirect effect of SR Strategies on PI

\begin{tabular}{|c|c|c|c|c|c|c|}
\hline \multirow[b]{2}{*}{$\mathbf{H}$} & \multirow[b]{2}{*}{ 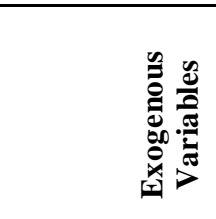 } & \multirow[b]{2}{*}{ 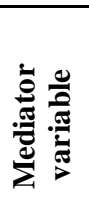 } & \multirow[b]{2}{*}{ 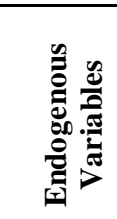 } & \multicolumn{3}{|c|}{ Path coefficients } \\
\hline & & & & 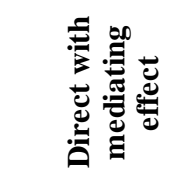 & 总 & 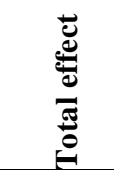 \\
\hline $\mathrm{H} 4 \mathrm{a}$ & Apology & & PI & 0.039 & -0.025 & 0.013 \\
\hline $\mathrm{H} 4 \mathrm{~b}$ & P. Solving & & PI & 0.002 & $0.327 * *$ & $0.330^{* * *}$ \\
\hline $\mathrm{H} 4 \mathrm{c}$ & Explanation & $\mathrm{RQ}$ & PI & 0.026 & $0.201 * *$ & $0.227 * *$ \\
\hline $\mathrm{H} 4 \mathrm{~d}$ & Compensation & & PI & 0.062 & $0.161 * *$ & $0.223 * *$ \\
\hline $\mathrm{H} 4 \mathrm{e}$ & Follow-Up & & PI & -0.014 & $0.117 * *$ & $0.103^{*}$ \\
\hline
\end{tabular}

Relationship quality $=$ RQ, Patronage intentions $=$ PI. $-*$ Significant at $0.05, * *$ significant at 0.01

For hypotheses $\mathrm{H} 5$ and $\mathrm{H} 6$, we found that speed of recovery moderated the positive relationship between making apology strategy $(\beta=0.088, \mathrm{p}$-value $=0.032)$, providing explanation $(\beta=0.094$, $\mathrm{p}$-value $=0.025)$, follow-up strategy $(\beta=0.103$, $p$-value $=0.015)$ and relationship quality. The results refer to $\mathrm{R} 2$ of RQ is 0.629 , meaning that service recovery strategies with the speed of recovery technique explain about $63 \%$ of the variation in RQ between internet customers and service providers as a dependent variable. We have found that our model has a great predictive relevance as the Q2 value of RQ is $(0.679)$.

In addition, we found that empathy moderated the positive relationship between problem solving strategy ( $\beta=$ 0.095 , $p$-value $=0.024)$, providing explanation $(\beta=0.090, p$-value $=0.030)$ and relationship quality. The results refer to $\mathrm{R} 2$ of $\mathrm{RQ}$ is 0.582 , meaning that service recovery strategies with the empathy technique explain about $58 \%$ of the variation in RQ between internet customers and service providers as a dependent variable. The Q2 value of RQ (0.670), which is well above zero, indicating the large predictive relevance of the PLS path model. So, the hypotheses $\mathrm{H} 4 \mathrm{a}, \mathrm{H} 4 \mathrm{~b}$ partially supported.

Table 6. Moderating effect of speed and empathy on the SR strategies effect on RQ

\begin{tabular}{llccl}
\hline H & \multicolumn{1}{c}{$\begin{array}{c}\text { Exogenous } \\
\text { variables }\end{array}$} & $\begin{array}{c}\text { Endogenous } \\
\text { Variables }\end{array}$ & $\begin{array}{c}\text { Path } \\
\text { coefficients }\end{array}$ & P-value \\
\hline H5a & Apology * Speed & RQ & 0.088 & $0.032^{*}$ \\
H5b & P. Solving * Speed & RQ & -0.010 & 0.417 \\
H5c & Explanation * Speed & RQ & 0.094 & $0.025^{*}$ \\
H5d & Compensation * Speed & RQ & 0.051 & 0.146 \\
H5e & Follow-Up * Speed & RQ & 0.103 & $0.015^{*}$ \\
H6a & Apology * Empathy & RQ & -0.064 & 0.091 \\
H6b & P. Solving * Empathy & RQ & 0.095 & $0.024^{*}$ \\
H6c & Explanation * Empathy & RQ & 0.090 & $0.030^{*}$ \\
H6d & Compensation * Empathy & RQ & -0.032 & 0.254 \\
H6e & Follow-Up * Empathy & RQ & 0.046 & 0.169 \\
\hline
\end{tabular}

Relationship quality $=\mathrm{RQ}$, Patronage intentions $=$ PI. $-*$ Significant at 0.05 , ** significant at 0.01

\section{Discussion}

Our study mainly aims to understand the relationship between service recovery strategies, relationship quality, and patronage intentions, as well as testing the mediating role of relationship quality in the relationship between SR strategies and consumer's patronage intentions and the moderating role of both recovery speed and empathy in the link between SR strategies and relationship quality. Moreover, providing effective practical recommendations to the internet service firm's managers.

We have found a significant positive effect for four SR strategies on PI and a similar result on RQ. The only SR strategy that was not found to have a significant effect has been making an Apology. This confirmed that SR strategies are necessary to maintain customers and create positive WOM in addition to deep the customer's intention to revisit the internet provider and continue dealing with him. Our results are also consistent with Lee et al. (2009) on that problem solving directly influences customer's patronage intentions.

SR strategies have a positive impact on RQ as well. This confirmed that SR strategies as an aspect of service quality deepen the quality of the long-term relationship between service provider and its customers. SR strategies 
are an effective way to increase customer satisfaction, which in turns increase trust in the provider and create customer commitment toward it. These results are on the same page with other results we have found in the existing literature (Tax et al., 1998; Wirtz and Mattila, 2004; Duffy et al., 2006; Kim, 2007; DeWitt et al., 2008; Komunda and Osarenkhoe, 2012; Yaya et al., 2013; Kandulapati and Bellamkonda, 2014; Stratemeyer et al., 2014) that SR strategies will enhance relationship quality.

We believe that the strange result for the making an apology strategy can be related to the specific Egyptian market. Egyptian Internet customers may not find this strategy effective as (1) internet services are really prone to failures, according to industry reports; (2) Egyptian customers' income is usually low so customers may prefer those strategies letting them have some sort of material compensation. These findings are consistent with Levesque and McDogugall (2000) viewpoint that an apology is better than none, but it alone is relatively ineffective when a customer endured a large loss (i.e. the case of a core service failure).

As expected from the study of the previous literature on Relationship Quality (Choi and Chu, 2001; Wirtz and Mattila, 2004; Sadachar, 2014; Park et al., 2015; Sharma, 2015) we have found a significant positive effect for it on patronage intentions. This highlights that the quality of relationship influences customer behavioral responses. This confirmed that relationship quality is very important to create or building customer loyalty and then create competitive advantage (Doaei et al., 2011).

Looking at the indirect effect of SR strategies on PI we have found that RQ fully mediated the impact of the same SR strategies (namely, problem-solving, providing explanation, compensation, and follow up). The results show that these strategies will increase the relationship quality between service providers and its customers depending on how the company dealt with the service failure and that they will help in creating a better attitude towards the company if they are carried on in a proper way. These results are partially consistent with those found by Wirtz and Mattila, 2004 i.e. service recovery satisfaction mediated the positive relationship between some SR strategies and repatronage intentions.

We have found that speed of recovery moderates the positive impact of several SR strategies (namely, apology, providing an explanation, and follow -up) on RQ. These results confirmed the role of recovery speed on improving the relationship between SR strategies and RQ.

In particular, we have found that when making an apology strategy is coupled with the speed of recovery it can have a small, but significant, positive effect on RQ. It follows that, if the provider makes an apology while being fast in solving the problem, it may still increase the customer satisfaction. A similar result has been found for providing explanations and following-up. These strategies will strengthen the customer's trust on the provider, which in turns affect positive word of mouth and repurchase intentions and likelihood to revisit.

Finally, our results highlight that an empathic approach enhances the effectiveness of problem solving and providing explanations on RQ. When the provider employees appear empathic and able to feel for the customer's plight or dilemma, while solving customer problems, they may be more effective in satisfying the customer, which in turn will strengthen the customers trust on the provider and maintain the relationship with provider, which affect his or hers behavioral responses. These two results confirmed the important role of speed of recovery and empathy techniques to support the influence of SR strategies on relationship quality aspects.

\section{Conclusions}

This article let us improve the theoretical knowledge on the relationship between the SR strategies, relationship quality and customer patronage intentions in the internet industry context. Previous studies have found evidence that some SR strategies act as a direct cognitive antecedent to repatronage intentions as an aspect of PI (Wirtz and Mattila, 2004). In addition, problem solving acts as a direct antecedent to retail patronage intentions (Lee et al., 2009). More recent research shows that SR strategies directly affect service recovery satisfaction (Wirtz and Mattila, 2004; Kim, 2007; Duffy et al., 2006; Komunda and Osarenkhoe, 2012; Yaya et al., 2013; Kandulapati and Bellamkonda, 2014; Stratemeyer et al., 2014; Mostafa et al. (2014) and customer trust (DeWitt et al., 2008) as a sub-components of relationship quality. In addition, some aspects of relationship quality influence patronage intentions (Sadachar, 2014; Park et al., 2015; Sharma, 2015).

In this work, we have provided the contribution of providing evidence that most SR strategies (problem solving, providing an explanation, compensation, and follow-up) can really affect customer patronage intentions. In addition, our research shows that RQ mediates the effect of SR strategies (problem solving, providing an explanation, compensation, and follow-up) on PI. This indicates that the more effective the SR strategies are the better the relationship quality will be, and the more these strategies will satisfy the customer and the more they will create trust and commitment the stronger their effect will be. This highlights the need to take into account 
the relationship quality between service providers and their customers and its essential role in enhancing PI. Furthermore, the speed of recovery and empathy with customer's techniques can enhance the impact of some SR strategies on RQ (namely speed of recovery technique for an apology, explanations, follow-up strategies, and empathy technique for both problem-solving explanations strategies). Moreover, our finding supports the idea that apologies have no significant effect on RQ alone and, indirectly, on PI. Consequently, they cannot be considered as an effective SR strategy if they are not coupled with some other SR strategy or, at the very least, the service provider is able to deal quickly with the problem itself.

Our findings regarding making an apology strategy, open the way to a more in-depth research effort to understand which specific services from ISPs, can be really considered as core services (e.g., denial or unavailability of service), and which of them are service encounter failure / process failure (e.g., lack of civility and non-response and the lack of the existence of personal service). On the other hand, as previously noted, this can be linked with a specific cultural attribute of customers in Egypt so these results would benefit from further validation in different cultures.

This article can help ISPs management as well. We confirm that a successful relationship between service provider and its customers are largely determined by maintaining long-term valuable relations. When the customers feel that, their provider is trying to provide a high-quality service and that it is interested to satisfy them, then customers will appreciate its efforts and will have more trust in it. All this previous feelings and attitudes will help to create a stable relationship that, in turn, will reflect in customers' patronage intentions.

In order to improve that long-term relationship and to get more benefits, managers should concentrate on service recovery strategies especially the intangible ones and train employees how to apply these strategies quickly and with empathy. Furthermore, internet providers must know that essential strategies are problem-solving and providing real explanations to customer and support with appropriate compensation and do not forget to follow up customers to ensure that all is going well, all of this will enhance the service provider competitive advantage.

Finally, despite its contributions, the current study has some limitations, which provide directions for further research. First, this study mainly depends on five service recovery strategies namely: apology, problem solving, providing explanations, compensation, and follow-up to identify its effects on patronage intentions as well as it examined the moderating role of both speed of recovery and empathy in the relationship between SR strategies and PI. According to our findings, all direct paths are supported despite the ones between apology and both relationship quality and patronage intentions. Therefore, future researchers may want to examine the combined effect of apology with each of the other four strategies (e.g. apology $\times$ problem solving) to understand the consequences of a combined strategy, and this may generate some meaningful insights. Second, this study puts emphasis on exploring the effect of SR strategies on PI and it looks only at the mediating effect by relationship quality, therefore, we expect that customer gratitude might have a meaningful mediating role to investigate the relationship between SR strategies and patronage intentions. Third, our study not found a significant influence of apology as service recovery strategies on relationship quality or patronage intentions attributes, so, further research may be concentrated on retesting our proposed model in other settings, moreover, if these other contexts have a tighter interaction between providers and consumers (e.g. the hotel industry). Finally, further studies may give more attention to those issues related to a cross-cultural approach.

\section{References}

Ali, M. F. S. (2016). Critical Firm-based Enablers-Mediators-Outcomes (CFEMOs): ANew Integrated Model for Product Innovation Performance Drivers in the Context of US Restaurants, Plymouth University. https://doi.org/10.1016/j.jretconser.2008.11.007

Anderson, E., \& Weitz, B. (1989). Determinants of continuity in conventional industrial channel dyads. Marketing science, 8(4), 310-323. https://doi.org/10.1287/mksc.8.4.310

Andreassen, T. (2000). Antecedents to satisfaction with service recovery. European Journal of Marketing, 34(1/2), 156-175. http://dx.doi.org/10.1108/03090560010306269

Baker, J., Parasuraman, A., Grewal, D., \& Voss, G. B. (2002). The influence of multiple store environment cues on perceived merchandise value and patronage intentions. Journal of marketing, 66(2), 120-141. https://doi.org/10.1509/jmkg.66.2.120.18470

Battaglia, D., Borchardt, M., Afonso Sellitto, M., \& Medeiros Pereira, G. (2012). Service recovery: a method for assessing performance. Business Process Management Journal, 18(6), 949-963. http://dx.doi.org/10.1108/14637151211283366

Bell, C. R., \& Zemke, R. E. (1987). Service breakdown: the road to recovery. Management review, 10, 3-352. 
Bitner, M. J., Brown, S. W., \& Meuter, M. L. (2000). Technology infusion in service encounters. Journal of the Academy of marketing Science, 28(1), 138-149. https://doi.org/10.1177/0092070300281013

Boshoff, C. (1999). RECOVSAT: An instrument to measure satisfaction with transaction-specific service recovery. Journal of service research, 1(3), 236-249. https://doi.org/10.1177/109467059913005

Boshoff, C., Hoogendoorn, P. M., \& van der Kraan, Y. (2005). A differentiated approach to service recovery. Nyenrode Research Group working paper series, (05-03).

Cassel, C. M., Hackl, P., \& Westlund, A. H. (2000). On measurement of intangible assets: a study of robustness of partial least squares. Total Quality Management, 11(7), 897-907. https://doi.org/10.1080/09544120050135443

Chang, C. C. (2004). The effect of choice and perceived control on customer satisfaction: The psychology of service recovery, Purdue University.

Choi, B., \& La, S. (2013). The impact of corporate social responsibility (CSR) and customer trust on the restoration of loyalty after service failure and recovery. Journal of Services Marketing, 27(3), 223-233. https://doi.org/10.1108/08876041311330717

Choi, T. Y., \& Chu, R. (2001). Determinants of hotel guests' satisfaction and repeat patronage in the Hong Kong hotel industry. International Journal of Hospitality Management, 20(3), 277-297. https://doi.org/10.1016/S0278-4319(01)00006-8

Chueh, T. Y., Wang, J. H., \& Liao, H. H. (2014). Effects of service recovery on customer satisfaction and relationship retention in catering industry. Anthropologist, 17(3), 857-863.

Claycomb, C., \& Martin, C. L. (2013). Building customer relationships: an inventory of service providers' objectives and practices. Journal of Services Marketing, 16(3), 615-635. https://doi.org/10.1108/EUM0000000006109

Crosby, L. A., Evans, K. R., \& Cowles, D. (1990). Relationship quality in services selling: an interpersonal influence perspective. The journal of marketing, 54(3), 68-81. https://doi.org/10.2307/1251817

Darian, J. C., Wiman, A. R., \& Tucci, L. A. (2005). Retail patronage intentions: the relative importance of perceived prices and salesperson service attributes. Journal of Retailing and Consumer Services, 12(1), 15-23. https://doi.org/10.1016/j.jretconser.2004.01.002

De Ruyter, K., \& Wetzels, M. (2000). Customer equity considerations in service recovery: a cross-industry perspective. International Journal of Service Industry Management, 11(1), 91-108. https://doi.org/10.1108/09564230010310303

Del Rio-Lanza, A. B., Vázquez-Casielles, R., \& Díaz-Martín, A. M. (2009). Satisfaction with service recovery: Perceived justice and emotional responses. Journal of Business Research, 62(8), 775-781. https://doi.org/10.1016/j.jbusres.2008.09.015

DeWitt, T., Nguyen, D. T., \& Marshall, R. (2008). Exploring customer loyalty following service recovery: The mediating effects of trust and emotions. Journal of Service Research, 10(3), 269-281. https://doi.org/10.1177/1094670507310767

Diddi, S., \& Niehm, L. S. (2016). Corporate Social Responsibility in the Retail Apparel Context: Exploring Consumers' Personal and Normative Influences on Patronage Intentions. Journal of Marketing Channels, 23(1-2), 60-76. https://doi.org/10.1080/1046669X.2016.1147892

Doaei, H., Rezaei, A., \& Khajei, R. (2011). The impact of relationship marketing tactics on customer loyalty: the mediation role of relationship quality. International Journal of Business Administration, 2(3), 83-93. https://doi.org/10.5430/ijba.v2n3p83

Dorsch, M. J., Swanson, S. R., \& Kelley, S. W. (1998). The role of relationship quality in the stratification of vendors as perceived by customers. Journal of the Academy of marketing Science, 26(2), 128-142. https://doi.org/10.1177/0092070398262004

Duffy, J. A. M., Miller, J. M., \& Bexley, J. B. (2006). Banking customers' varied reactions to service recovery strategies. International Journal of Bank Marketing, 24(2), 112-132. https://doi.org/10.1108/02652320610649923

Ennew, C., \& Schoefer, K. (2003). Service failure and service recovery in tourism: A review. Christel DeHaan Tourism and Travel Research Institute, Nottingham University Business School. 
Fornell, C., \& Cha, J. (1994). Partial least squares. Advanced methods of marketing research, 407(3), 52-78.

Fornell, C., \& Larcker, D. F. (1981). Evaluating structural equation models with unobservable variables and measurement error. Journal of marketing research, 18(1), 39-50. https://doi.org/10.2307/3151312

Fornell, C., \& Wernerfelt, B. (1987). Defensive marketing strategy by customer complaint management: a theoretical analysis. Journal of marketing research, 24(4), 337-346. https://doi.org/10.2307/3151381

Ganesh, J., Reynolds, K. E., \& Luckett, M. G. (2007). Retail patronage behavior and shopper typologies: a replication and extension using a multi-format, multi-method approach. Journal of the Academy of Marketing Science, 35(3), 369-381. https://doi.org/10.1007/s11747-007-0038-0

Gittell, J. H. (2002). Relationships between service providers and their impact on customers. Journal of Service Research, 4(4), 299-311. https://doi.org/10.1177/1094670502004004007

Grewal, D., Baker, J., Levy, M., \& Voss, G. B. (2003). The effects of wait expectations and store atmosphere evaluations on patronage intentions in service-intensive retail stores. Journal of retailing, 79(4), 259-268. https://doi.org/10.1016/j.jretai.2003.09.006

Gronroos, C. (1988). Service quality: The six criteria of good perceived service. Review of business, 9(3), 10-13.

Hair, J. F. Jr, Black, W. C., Babin, B. J., Anderson, R. E., \& Tatham, R.L. (2006), Multivariate Data Analysis, 6th ed., Prentice Hall, Upper Saddle River, NJ.

Hart, C. W., Heskett, J. L., \& Sasser Jr, W. E. (1989). The profitable art of service recovery. Harvard business review, 68(4), 148-156.

Hennig, T. T., \& Klee, A. (1997). The impact of customer satisfaction and relationship quality on customer retention: A critical reassessment and model development. Psychology and marketing, 14(8), 737-764. https://doi.org/10.1002/(SICI)1520-6793(199712)14:8<737::AID-MAR2>3.0.CO;2-F

Johnston, R., \& Clark, G. (2005), Service Operations Management Improving Service Delivery, second edition. Pearson Education Limited.

Jones, T., Fox, G. L., Taylor, S. F., \& Fabrigar, L. R. (2010). Service customer commitment and response. Journal of Services Marketing, 24(1), 16-28. https://doi.org/10.1108/08876041011017862

Kandulapati, S., \& Bellamkonda, R. S. (2014). Examining the structural relationships of service recovery, customer satisfaction and image in online retailing. Operations and Supply Chain Management, 7(2), 70-78.

Kanyan, A., Andrew, J. V., Ali, J. K., \& Beti, M. M. (2015). Building Customer Relationship for Gaining Customer Loyalty in the Pharmaceutical Industry. Journal of Advanced Management Science, 3(4), 319-322.

Kau, A. K., \& Wan- Yiun Loh, E. (2006). The effects of service recovery on consumer satisfaction: a comparison between complainants and non-complainants. Journal of Services Marketing, 20(2), 101-111. https://doi.org/10.1108/08876040610657039

Kim, G. S. (2007). The service recovery strategies, customer satisfaction, customer loyalty. Asian Journal on Quality, 8(1), 76-86. https://doi.org/10.1108/15982688200700005

Kim, T., Jung-Eun Yoo, J., \& Lee, G. (2012). Post-recovery customer relationships and customer partnerships in a restaurant setting. International Journal of Contemporary Hospitality Management, 24(3), 381-401. https://doi.org/10.1108/09596111211217879

Klarner, P., Sarstedt, M., Hoeck, M., \& Ringle, C. M. (2013). Disentangling the effects of team competences, team adaptability, and client communication on the performance of management consulting teams. Long Range Planning, 46(3), 258-286. https://doi.org/10.1016/j.lrp.2013.03.001

Kock, N., \& Lynn, G. S. (2012). Lateral collinearity and misleading results in variance-based SEM: An illustration and recommendations. Journal of the Association for Information Systems, 13(7), 546-580.

Komunda, M., \& Osarenkhoe, A. (2012). Remedy or cure for service failure? Effects of service recovery on customer satisfaction and loyalty. Business Process Management Journal, 18(1), 82-103. https://doi.org/10.1108/14637151211215028

Krishna, A., Dangayach, G. S., \& Jain, R. (2011). Service recovery: Literature review and research issues. Journal of Service Science Research, 3(1), 71-121.

Lacey, R., Suh, J., \& Morgan, R. M. (2007). Differential effects of preferential treatment levels on relational 
outcomes. Journal of Service Research, 9(3), 241-256. https://doi.org/10.1177/1094670506295850

Lee, H. J., Fairhurst, A. E., \& Lee, M. Y. (2009). The importance of self-service kiosks in developing consumers' retail patronage intentions. Managing Service Quality: An International Journal, 19(6), 687-701. https://doi.org/10.1108/09604520911005071

Levesque, T. J., \& McDougall, G. H. G. (2000). Service Problems and Recovery Strategies: An Experiment. Journal of Administrative Sciences, 21, 20-37. https://doi.org/10.1111/j.1936-4490.2000.tb00204.x

Liao, H. (2007). Do it right this time: the role of employee service recovery performance in customer-perceived justice and customer loyalty after service failures. Journal of applied psychology, 92(2), 475. https://doi.org/10.1037/0021-9010.92.2.475

Li-Hua, I. (2006). Perceptions of service failure, service recovery strategies, and behavioral intentions of hotel guests in Orlando, Florida.

Lin, I. H. (2006). Perceptions of Service Failure, Service Recovery Strategies, and Behavioral Intentions of Hotel Guests in Orlando, Florida. Ph.D. Dissertation, Lynn University.

Linares, R. T. (2012). An Examination of Relationship Marketing as a Determinant of Commitment and Loyalty in College and University Students. Nova Southeastern University.

McCollough, M. A., Berry, L. L., \& Yadav, M. S. (2000). An empirical investigation of customer satisfaction after service failure and recovery. Journal of service research, 3(2), 121-137. https://doi.org/10.1177/109467050032002

Michel, S., Bowen, D., \& Johnston, R. (2009). Why service recovery fails: Tensions among customer, employee,

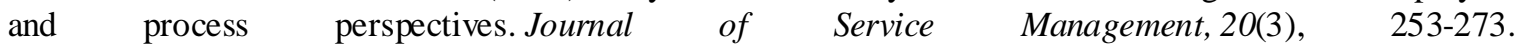
https://doi.org/10.1108/09564230910964381

Miller, J. L., Craighead, C. W., \& Karwan, K. R. (2000). Service recovery: a framework and empirical investigation. Journal of operations Management, 18(4), 387-400. http://dx.doi.org/10.1016/S0272-6963(00)00032-2

Mittal, V., Ross Jr, W. T., \& Baldasare, P. M. (1998). The asymmetric impact of negative and positive attribute-level performance on overall satisfaction and repurchase intentions. Journal of Marketing, 62, 33-47. https://doi.org/10.2307/1251801

Moorman, C., Deshpande, R., \& Zaltman, G. (1993). Factors affecting trust in market research relationships. Journal of Marketing, 57, 81-101. https://doi.org/10.2307/1252059

Moorman, C., Zaltman, G., \& Deshpande, R. (1992). Relationships between providers and users of market research: The dynamics of trust within and between organizations. Journal of marketing research, 29(3), 314-329. https://doi.org/10.2307/3172742

Morgan, R. M., \& Hunt, S. D. (1994). The commitment-trust theory of relationship marketing. Journal of marketing, 58, 20-38. https://doi.org/10.2307/1252308

Mostafa, R. R., Lages, C., \& Sääksjärvi, M. (2014). The CURE scale: a multidimensional measure of service recovery strategy. Journal of Services Marketing, 28(4), 300-310. https://doi.org/10.1108/JSM-09-2012-0166

Najjar, M. S., Smith, A. K., \& Kettinger, W. J. (2010), 'Stuff' Happens: A Theoretical Framework for Internal IS Service Recovery, In Americas Conference on Information Systems, 12, 1-8.

Ogwo, O. E., \& Igwe, S. R. (2012). Some key factors influencing attitudes to patronage of GSM services: the Nigerian experience. International Journal of Business and Management, 7(18), 82-91. https://doi.org/10.5539/ijbm.v7n18p82

Ok, C. (2004). The effectiveness of service recovery and its role in building long-term relationships with customers in a restaurant setting, Kansas State University.

Oliver, R. L. (1981). Measurement and e valuation of satisfaction processes in retail settings. Journal of Retailing, 57(1), 515-529.

Oliver, R. L. (1997). Varieties of value in the consumption satisfaction response. Advances in Consumer Research, 23(7), 247-254.

Orsingher, C., Valentini, S., \& de Angelis, M. (2010). A meta-analysis of satisfaction with complaint handling in services. Journal of the Academy of Marketing Science, 38(2), 169-186. 
https://doi.org/10.1007/s11747-009-0155-z

Pan, Y., \& Zinkhan, G. M. (2006). Determinants of retail patronage: a meta-analytical perspective. Journal of retailing, 82(3), 229-243. https://doi.org/10.1016/j.jretai.2005.11.008

Parasuraman, A., Berry, L. L., \& Zeithaml, V. A. (1991). Understanding customer expectations of service. MIT Sloan Management Review, 32(3), 39-48.

Park, J. J., \& Park, J. W. (2016). Investigating the effects of service recovery quality elements on passengers' behavioral intention. Journal of Air Transport Management, 53, 235-241. https://doi.org/10.1016/j.jairtraman.2016.03.003

Park, M. J., Choi, H., Kim, S. K., \& Rho, J. J. (2015). Trust in government's social media service and citizen's patronage behavior. Telematics and Informatics, 32(4), 629-641. https://doi.org/10.1016/j.tele.2015.02.006

Patney, M. B. (2010). Indian consumers and their mall patronage: Application of cultural-self and the theory of planned behavior to patronage intentions. Iowa State University.

Petzer, D. J., Steyn, T. F. J., \& Mostert, P. G. (2009). Customer retention practices of small, medium and large hotels In South Africa: An exploratory study. African Journal of Marketing Management, 1(1), 032-042.

Rahman, O., Wong, K. K. K., \& Yu, H. (2016). The effects of mall personality and fashion orientation on shopping value and mall patronage intension. Journal of Retailing and Consumer Services, 28, 155-164. https://doi.org/10.1016/j.jretconser.2015.09.008

Sadachar, A. (2014). Indian consumers' patronage intention toward shopping malls: Application of an experience economy perspective. Iowa State University.

San Martín, H., \& Herrero, Á. (2012). Influence of the user's psychological factors on the online purchase intention in rural tourism: Integrating innovativeness to the UTAUT framework. Tourism Management, 33(2), 341-350. https://doi.org/10.1016/j.tourman.2011.04.003

Sarstedt, M., Ringle, C. M., Smith, D., Reams, R., \& Hair, J. F. (2014). Partial least squares structural equation modeling (PLS-SEM): A useful tool for family business researchers. Journal of Family Business Strategy, 5(1), 105-115. https://doi.org/10.1016/j.jfbs.2014.01.002

Sharma, D. (2015). Examining the influence of service quality on customer satisfaction and patronage intentions in convenience store industry. International Journal of Business and Globalisation, 15(2), 152-170. https://doi.org/10.1504/JJBG.2015.071154

Smith, B. (1998). Buyer - seller relationships: bonds, relationship management, and sex - type. Canadian Journal of Administrative Sciences, 15(1), 76-92. https://doi.org/10.1111/j.1936-4490.1998.tb00153.x

Smith, J. S. (2007). An examination of the relationship between service reco very system structure, service operating environment, and recovery performance. Master Thesis, University of Southern Indiana.

Stratemeyer, A. W., Geringer, S. D., \& Canton, A. (2014). An Exploratory Investigation of the Effects of Service Failures and Recovery Efforts on Customer Satisfaction. American Journal of Management, 14(3), 20-28.

Tagashira, T., \& Minami, C. (2016). The effects of online and offline information sources on multiple store patronage. Australasian Marketing Journal (AMJ), 24(2), 116-124. https://doi.org/10.1016/j.ausmj.2016.02.007

Tax, S. S., Brown, S. W., \& Chandrashekaran, M. (1998). Customer evaluations of service complaint experiences: implications for relationship marketing. Journal of marketing, 62(2), 60-76. https://doi.org/10.2307/1252161

Tronvoll, B. (2011). Negative emotions and their effect on customer complaint behaviour. Journal of Service Management, 22(1), 111-134. https://doi.org/10.1108/09564231111106947

Vesel, P., \& Zabkar, V. (2010). Relationship quality evaluation in retailers' relationships with consumers. European Journal of Marketing, 44(9/10), 1334-1365. https://doi.org/10.1108/03090561011062871

Wang, Y. S., Yeh, C. H., \& Liao, Y. W. (2013). What drives purchase intention in the context of online content services? The moderating role of ethical self-efficacy for online piracy. International Journal of Information Management, 33(1), 199-208. https://doi.org/10.1016/j.ijinfomgt.2012.09.004

Wirtz, J., \& Mattila, A. S. (2004). Consumer responses to compensation, speed of recovery and apology after a service failure. International Journal of service industry management, 15(2), 150-166. 
https://doi.org/10.1108/09564230410532484

Wong, Y. H., Hung, H., \& Chow, W. K. (2007). Mediating effects of relationship quality on customer relationships: an empirical study in Hong Kong. Marketing Intelligence and Planning, 25(6), 581-596. https://doi.org/10.1108/02634500710819950

Woo, K. S., \& Ennew, C. T. (2004). Business-to-business relationship quality: An IMP interaction-based conceptualization and measurement. European Journal of Marketing, 38(9/10), 1252-1271. https://doi.org/10.1108/03090560410548960

Yaya, L., Marimon, F., \& Casadesus, M. (2013). Can ISO 9001 improve service recovery? Industrial Management and Data Systems, 113(8), 1206-1221. https://doi.org/10.1108/IMDS-03-2013-0150

Zeithaml, V. A., Berry, L. L., \& Parasuraman, A. (1996). The behavioral consequences of service quality. Journal of Marketing, 60, 31-46. https://doi.org/10.2307/1251929

Zeithaml, V. A., Parasuraman, A., \& Berry, L. L. (1990). Delivering quality service: Balancing customer perceptions and expectations. Simon and Schuster.

Zemke, R., \& Bell, C. (1990). Service recovery: Doing it right the second time. Training, 27(6), 42-48.

Zolfagharian, M. A., \& Paswan, A. (2009). Perceived service innovativeness, consumer trait innovativeness and patronage intention. Journal of Retailing and Consumer Services, 16(2), 155-162.

https://doi.org/10.1016/j.jretconser.2008.11.007 
Appendix A: Items of questionnaire

\begin{tabular}{|c|c|}
\hline Code & Items \\
\hline SR & Service recovery \\
\hline & A. Making an apology (adapted from Liao, 2007, Kim, 2007, Boshoff et al.,2005) \\
\hline SR1 & Internet provider employees apologizes for any problem that occurs to me. \\
\hline SR2 & Employees expressed their responsibilities when the service slow or interruption occurs. \\
\hline SR3 & Internet provider announces its regret about moral damage due to service slow or interruption. \\
\hline SR4 & Internet provider apologizes for the financial losses due to service slow or interruption. \\
\hline SR5 & Internet provider has clear rules to apologize to its customers. \\
\hline & B. Problem solving ( adapted from Liao, 2007, Kim, 2007, Del Rio-Lanza et al., 2009) \\
\hline SR6 & I felt that Internet provider employees have sufficient skills to solve my problem. \\
\hline SR7 & Employees did everything possible to solve customer problem. \\
\hline SR8 & The procedures followed by Internet provider to resolve my problem seems be clear. \\
\hline SR9 & The procedures followed by Internet provider to resolve my problem seems be effective. \\
\hline SR10 & I felt that my problem was over (ended) after the service recovery process. \\
\hline & C. Providing explanation ( adapted from Liao, 2007, Boshoff et al.,2005, Kau and Loh, 2006) \\
\hline SR11 & Internet provider employees interested to respond to my inquiries about the service provided. \\
\hline SR12 & Employees explain the service slow or interruption reasons to customers who complaints. \\
\hline SR13 & Employees gave me a reasonable explanation for service failure. \\
\hline SR14 & Employee's replies to my explanations seems clearly. \\
\hline & D. Speed of recovery( adapted from Liao, 2007, Boshoff et al.,2005) \\
\hline SR15 & Employees respond immediately to my inquiries and complaints. \\
\hline SR16 & My problem was solved within reasonable time. \\
\hline & $\begin{array}{l}\text { E. Empathy (adapted from Liao, 2007, Boshoff et al.,2005, Kau and Loh, 2006, Del Rio-Lanza et } \\
\text { al., 2009) }\end{array}$ \\
\hline SR17 & Despite the sharpness in my talking with the employee, he treated me with respect. \\
\hline SR18 & Employees listen with attention to my complaint. \\
\hline SR19 & I feel a tone of honesty from the employee when answering my questions. \\
\hline SR20 & F. Compensation (adapted from Kim, 2007, Boshoff et al.,2005) \\
\hline SR21 & $\begin{array}{l}\text { Internet provider compensate me for losses resulting from the service slow. } \\
\text { Internet provider compensate me for losses resulting from the service interruption. }\end{array}$ \\
\hline SR22 & $\begin{array}{l}\text { Internet provider is keen to provide compensation appropriate with the damage caused to its customers. } \\
\text { G. Follow up (adapted from Boshoff, 1999, Boshoff et al.,2005) }\end{array}$ \\
\hline SR23 & Internet provider is keen to tell me what was happen to solve my problem. \\
\hline SR24 & Internet provider seeks always to know the reaction of customers about service recovery process. \\
\hline SR25 & $\begin{array}{l}\text { Internet provider is keen to contact me after treating with my problems to ensure that the service is going } \\
\text { well. }\end{array}$ \\
\hline RQ & Relationship quality (adapted from Kim et al.,2012) \\
\hline SRS1 & The Internet provider response to my complaint about the service interruption better than I expected. \\
\hline SRS2 & The Internet provider response to my complaint about the service slows better than I expected. \\
\hline SRS3 & Overall, I like service recovery system of my Internet provider. \\
\hline SRS4 & Provider service recovery efforts achieve satisfactory results for me. \\
\hline SRS5 & I have a more positive attitude toward my internet provider. \\
\hline CT1 & The promises made by my internet provider are reliable. \\
\hline CT2 & I believe the company is trustworthy. \\
\hline CT3 & I trust the information provided by my internet provider. \\
\hline CT4 & The level of service provided by my internet provider makes me feel safe. \\
\hline $\mathrm{CC} 1$ & I feel emotionally attached to my internet provider \\
\hline $\mathrm{CC} 2$ & I would be very happy to continue dealing with this internet provider. \\
\hline $\mathrm{CC} 3$ & I feel a strong sense of belonging to my internet provider. \\
\hline $\mathrm{CC} 4$ & I think that my internet provider worth keeping the relationship with him. \\
\hline PI & Patronage Intentions ( adapted from Grewal et al., 2003; Zolfagharian and Paswan, 2009) \\
\hline PI 1 & I would be willing to recommend my friends and relatives to deal with my internet provider \\
\hline PI 2 & I do not intend to switch to a competitor of my internet provider. \\
\hline PI 3 & I would be willing to continue to get the services of this Internet provider in the near future. \\
\hline
\end{tabular}

\section{Copyrights}

Copyright for this article is retained by the author(s), with first publication rights granted to the journal.

This is an open-access article distributed under the terms and conditions of the Creative Commons Attribution license (http://creativecommons.org/licenses/by/4.0/). 